\title{
Community involvement in tourism: exploring the place image guided by the locals
}

\author{
Participación de la comunidad en el turismo: \\ explorando la imagen del lugar
}

\author{
Monica Pascoli \\ University of Udine \\ monica.pascoli@uniud.it
}

Summary: I. The impact of tourism and the paradigm of sustainability. -II. Approaches to sustainability in tourism.-III. Critics to the concept of community-based tourism - IV. On the concept of community.-V. Tourist imaginaries.-VI. Participation as practice: creating the image of a place. - VII. The research project.-VIII. The context of the research. -IX. Methodology.-X. First results. - XI. Conclusion

\begin{abstract}
This paper is intended as a contribution to the debate on tourism sustainability and the need to involve local communities in planning practices, key to sustainable tourism.

The community-based approach has been widely theorized and used in projects of sustainable tourism development, because it tends to maximize the participation of local population from the earliest stages of development and affect tourism policies, while also responding to the changing needs of contemporary tourists, especially in terms of development of niche and special-interest tourism.

The only exception is in the construction of the tourist imaginary: the involvement of the community in this fundamental sphere has always been scarce, with the result that often there is a strong imbalance - even dissonance - between the image promoted through the marketing, that continuously re-shaped by the locals and that experienced by the tourists. This contribution will explore the creation of tourism imaginary as negotiated activity.
\end{abstract}

Keywords: tourism, sustainability, participation, community-based tourism, imaginary.

Resumen: El enfoque community based a sido ampliamente teorizado y tomado en cuenta en los proyectos de desarrollo de turismo sostenible, porque permite de maximizar la participación de la población local desde las primeras etapas de desarrollo, influyendo positivamente en las politicas del turismo. Una excepción significativa ha sido la construcción de la imaginación turística: la 
participación de las comunidades siempre ha sido poco considerada, resultando un fuerte desequilibrio, hasta disonancia, entre la imagen promovida a través del marketing, la modelada por los lugareños y la experimentada por los turistas. Esta contribución es parte del debate sobre la sostenibilidad del turismo y la participación de las comunidades locales, con la intención de explorar el proceso de creación de una imaginación turística en tanto que actividad negociada.

Palabras clave: turismo, sostenibilidad, implicación, turismo comunitario e imaginario.

\section{The impact of tourism and the paradigm of sustainability}

Tourism development is without doubt one of the leading causes of environmental problems both in renowned holiday resorts and destinations that have only recently started to gain in popularity. The issues all arise from a range of factors linked to the presence of tourists, and more specifically, the type of tourism traditionally associated with the destination, its seasonality and the intrinsic nature of the destination: urban and mountain areas, for instance, differ extensively in their ability to bear heavy flows of tourists. These factors interact with each other in a cumulative manner and this explains why the effects of tourist development in a given area cannot be calculated by simply summing up all the impacts; the outcome instead is the result of their combination and transformation into elements of change that are hard to trace back to their original source ${ }^{1}$. Among the variables believed to have a significant impact on the environment are: the number of tourists present and type of activities carried out, the infrastructures built as a consequence of tourism territorial planning, the type and amount of information provided to tourists and their feedback in terms of expectations, the vulnerability of the local environment, both natural and man-made ${ }^{2}$.

Together with its impact on the environment, experts often highlight how tourism can trigger conflicts among the various people involved in the interaction. This issue first emerged in the Nineteen Seventies, when academics studying the social and cultural impact of tourism started viewing it as a factor of change, with all its negative consequences: it was

${ }^{1}$ Stephen Williams, Tourism geography (London-New York: Routledge, 1998), 100-

2 Chris Ryan, Recreational tourism. Demand and impacts (Clevendon: Channel View, 2003), 204-209 
- and is still - considered a momentous force, capable of shattering the fragile social and cultural balances existing in a given destination. The role of tourism as a factor of change and the might of its destructive impacts were evident in the more popular mass tourism resorts, be they on the Mediterranean coasts or further away from home. It was at that time that ground-breaking papers on the social and cultural impact of tourism were published: those works analyzed the effects of tourism on society, language, health, religion and ethics, as well as on the people's habits and customs, the local arts and crafts ${ }^{3}$.

Research on the social impact of tourism has been one of the most deeply investigated issues in social science. In a comprehensive overview on the subject, Deery et al. ${ }^{4}$ describe the development of this line of research, highlighting how it unfolded from a first descriptive and more explorative stage ${ }^{5}$, to one characterized by the creation of models to analyze tourism impacting factors, which was then followed by increasingly detailed investigations ${ }^{6}$. Some of these papers focus on the variety of interactions taking place between tourists and locals, describing how they are dynamic and subject to change. The elements potentially giving rise to clashes are numerous: the distance between value systems and social class; attitudes and behaviours of both tourists and locals, the different and often clashing expectations of both parties. The conflicts might occur at different levels: between clashing systems, when traditions and their underlying set of symbols are exploited for profit; or between individuals, usually in the

${ }^{3}$ Emanuel De Kadt, Tourism. Passport to development? (Oxford: Oxford University Press, 1979).

Valene Smith (ed), Hosts and guests. The anthropology of tourism (Philadelphia: University of Pennsylvania Press, 1977).

Louis Turner and John Ash, The golden hordes. International tourism and the pleasure periphery (London: Constable, 1975).

${ }^{4}$ Margaret Deery, Leo Jago, and Liz Fredline. "Rethinking Social Impacts of Tourism Research: A New Research Agenda". Tourism Management 33, no. 1 (2012): 64-73. https:// doi.org/10.1016/j.tourman.2011.01.026

${ }^{5}$ Liu, Juanita C., Pauline J. Sheldon and Turgut Var. "Resident perception of the environmental impacts of tourism". Annals of Tourism Research 14, no. 1 (1987): 17-37.

${ }^{6}$ Erik Cohen. "A phenomenology of tourist experiences". Sociology 13, no. 2 (1979): 179-201. Alister Mathieson and Geoffrey Wall, Tourism: economic, physical and social impacts (London: Longman, 1982). John Ap and John L. Crompton, "Developing and testing a tourism impact scale", Journal of Travel Research 37, no. 2 (1998): 120-130. Jeremy Boissevain, Coping with Tourists. European Reaction to Mass Tourism (OxfordNew York: Berghahn Books, 1996). Hwan-Suk Chris Choi and Ercan Sirakaya, "Measuring residents' attitude toward sustainable tourism: development of sustainable tourism attitude scale". Journal of Travel Research 43, no. 4 (2005): 380-394. Hasan Zafer Doğan, "Forms of adjustment: sociocultural impacts of tourism", Annals of Tourism Research 16, no. 2 (1989): 216-236. 
event of a controversial or disputed exploitation of natural and cultural assets ${ }^{7}$.

The conflicts that can be ascribed to tourism development not only occur between holiday-makers and residents, but also between residents and stakeholders, because they often end up competing for the same resources $^{8}$. Conflicts within a community are usually pre-existing, but are greatly amplified by the advent of tourism: its goal is to "sell" images that can be easily communicated to and understood by the wider public. In order to be more accessible, these images must be simplified through a process that defines them as opposites: the hazier, more complex concepts are simplified and their meaning is made understandable by identifying and comparing them with their antipode (for instance: novel/traditional; artificial/natural; processed/genuine; familiar/foreign).

However, as emphasized by Deery et al., research has often attempted to "provide lists of impacts without a clear understanding of how the perceptions of these impacts were formed and, more importantly, how such perceptions could be changed if necessary" .

Not all impacts are negative: Boissevain reminds us that one of the most important features of tourism is how it promotes consciousness, pride, confidence and solidarity among people living in a given destination ${ }^{10}$.

Studies on the social impacts of tourism are interlocked with the debate on sustainability. The first definition attempting to encompass the concept of sustainability ${ }^{11}$ in its entirety was elaborated in the late Nineteen Eighties by the World Commission on Environment and Development ${ }^{12}$.

7 Mike Robinson and Priscilla Boniface, eds., Tourism and Cultural Conflicts. (Wallingford: CABI, 1999): 9-10.

${ }^{8}$ Ibidem: 11-17.

9 Margaret Deery et alii, "Rethinking Social Impacts of Tourism Research...": 65.

${ }^{10}$ Boissevain, Jeremy. Coping with Tourists: 5.

${ }^{11}$ Hence including both the environmental concept of "sustainable use" and the more economic-oriented one of "sustainable growth".

${ }^{12}$ In its final report, the Commission defines sustainable development as that meeting "the needs of the present without compromising the ability of future generation to meet their own needs": a rather hazy definition.The United Nations' Conference on Environment and Development held in Rio de Janeiro and more specifically, the drafting of the action plan known as Agenda 21 made an attempt to pragmatize the concept of sustainable development, resulting in an organic set of guidelines involving action at international, national, regional and local levels. World Commission on Environment and Development. Our Common Future. 1987. https://sustainabledevelopment.un.org/ content/documents/5987our-common-future.pdf. Ibidem: 43. Martin Mowforth and Ian Munt, Tourism and sustainability. New tourism in the Third World (London-New York: Routledge, 1998). Fabio Pollice, Territori del turismo. Una lettura geografica delle politiche del turismo (Milano: FrancoAngeli, 2002). 
The goal of "sustainability" continues to be an important issue in the public debate concerning the ability to compromise between the needs for economic development and responsibility ethics ${ }^{13}$. Sustainability has been defined as a "bridge concept" spanning between the dissimilar needs of opposite stakeholders and the paradigms of eco- and anthropocentrism ${ }^{14}$. This notion of sustainable development is disputed, as evident when attempting to translate it into practice ${ }^{15}$.

As regards tourism, the concept of sustainable development encompasses various dimensions: ecological, economical, social and cultural. It is our intent to focus on the latter two aspects. Social sustainability implies that the residents must increase their control over their lives, preserving and indeed reinforcing their identity and community cohesion, whilst cultural sustainability requires that development preserve and foster the meaningfulness, practices and societies of which they are the hallmark. As reconstructed by Saarinen ${ }^{16}$, the complexity of the concept and its multidimensionality have led many authors to believe there is no precise definition of "sustainable tourism" and for this reason "has sometimes been understood as an ideology and point of view rather than an exact operational definition"17.

Mainstay of the concept of sustainable tourism outlined so far is the involvement of all social, economical and political authorities of the territory and more in general, the subjects that either directly or indirectly take part in the process of tourism development. A sustainability-driven policy requires great attention towards local communities, which in theory should be the direct beneficiaries of the economic benefits brought about by tourism.

\section{Approaches to sustainability in tourism}

In tracing back the approaches to the concept of sustainability, Saarinen identifies a series of research focuses. The first can be defined as resource-

13 Alessandro Simonicca, "Teoria e prassi dell'heritage tourism". In Turismo e sostenibilità. Risorse locali e promozione turistica come valore, edited by Lucilla Rami Ceci, 133-155 (Roma: Armando Editore, 2005), 139-140.

${ }_{14}$ Stephen Page and Ross Dowling, Ecotourism (Harlow: Prentice Hall, 2002), 14-17.

15 Jim Macbeth, "Towards an Ethics Platform for Tourism". Annals of Tourism Research 32, no. 4 (2005): 966-967. Wall, Geoffrey. "Rethinking impacts of tourism". In Progress in Tourism and Hospitality Research 2, no. 3-4 (1996): 207-215. https://doi.org/10.1002/ pth.6070020302

16 Jarkko Saarinen, "Traditions of sustainability in tourism studies". Annals of Tourism Research 33, no. 4 (2006): 1121-1140. https://doi.org/10.1016/j.annals.2006.06.007

17 Ibidem: 1124 
based, hence strictly linked to the models of carrying capacity and limits of acceptable change. These two tools are functional to the implementation of the concept of sustainability during the planning stage. The analysis in this case is based on the assumption that tourism is a dynamic activity leading to permanent changes, some of which are perceived as negative: tourism has an impact, and if greater growth and development are required, the stakeholders involved must interact with the environment in new and better ways, changing their approach and/or level of interaction, but not the available resources. According to this line of study, limits to growth and impacts are both assessed on the grounds of the resources exploited by tourism, taking into account the original conditions, be they known or presumed; limits to growth can be therefore considered objective, and can be measured by appraising the characteristics of said resources and their transformation ${ }^{18}$.

The activity-based line of research, on the other hand, is characterised by a more relativistic approach: tourist activities develop differently, hence different are the responses to their impact. This type of approach is more industry-oriented and originates from the concept of life cycle: like many other products, the life cycle of a holiday resort can easily end if no reinvestment and renovation policies are implemented (ibidem: 1127-1129). Hence, if residents and the tourist sector are incapable of commitment, this could lead to a decline of the destination and ruin its image. This activitybased model is difficult to analyze, given its great variability: it is dynamic, because subject to continuous changes; relative, since it is defined through a constant process of comparison; multiple, given that it implies the appraisal of a variety of factors ${ }^{19}$.

A solution can be found by adopting a different type of approach, known in literature as community-approach, whereby the limits to tourist development are defined by negotiation, within a community-based framework ${ }^{20}$. In other words, the tourist industry can only offer economic and social benefits if a community-based approach is employed, ditching an exclusively business-oriented approach in favour of one addressing the local community ${ }^{21}$. The way a community responds to the opportunities and challenges arising from tourism depends on the type of contact between residents and tourists and the significance of the industry for the individuals

18 Jarkko Saarinen, “Traditions of sustainability in tourism studies": 1125-1127

19 Chris Ryan, Recreational tourism. Demand and impacts (Clevendon: Channel View, 2003), 132.

20 Jarkko Saarinen, "Traditions of sustainability in tourism studies": 1129-1131.

${ }^{21}$ Peter E. Murphy, Tourism. A community approach (New York: Methuen, 1985), 41-45. 
and for the community as a whole ${ }^{22}$. Participation takes shape thanks to a series of steps and practices carried out together with the residents. A community-based approach implies that sustainability is, or better, can be, defined though a negotiation process. By empowering the local communities, it is possible to define the growth limits in a beneficial manner for residents and local stakeholders: these become dynamic concepts, continuously defined and construed through negotiation processes. The community-based approach acknowledges the need to both promote the life quality of the residents and protect the resources ${ }^{23}$. Although community-based tourism entails a high degree of public participation, its detractors have underlined that in practice, local residents are rarely given the opportunity of responding to the programmes endorsed by public authorities and the private sector ${ }^{24}$.

\section{Critics to the concept of community-based tourism}

Blackstock, taking the cue from community development, provides a critical view of community-based tourism $(\mathrm{CBT})^{25}$. The author claims that there are three elements of conflict between these two approaches. One is linked to their aims: community-based tourism is not interested in the community as such, but only in tourist development, and this is the ultimate goal of any type of cooperation with the community ${ }^{26}$. Another element becomes evident by taking a critical view of the concept of community, and more specifically, the so-called atheoretical and apolitical approach to said concept: "This presentation of community is an ideal masquerading as social fact" 27 . In other words, CBT fails to take into account the heterogeneity, stratification and power structure of a community. Finally, the author also highlights how, in the end, economic interests linked to tourism development will always prevail on the those of the residents. Her conclusion is that "a socially equitable tourism industry is resisted as it challenges the vested interests of capital invested in tourism growth [...] the current conceptualization of CBT is naïve and unrealistic [...] CBT

22 Ibidem: 119.

23 Jarkko Saarinen, "Traditions of sustainability in tourism studies": 1127.

${ }_{24}$ Mick Smith and Rosaleen Duffy, The ethics of tourist development (London-New York: Routledge, 2003), 139.

25 Kirsty Blackstock, "A critical look at community based tourism”, Community Development Journal 40, no. 1 (2005): 39-49.

26 Ibidem: 41

27 Ibidem: 42 
focuses on maximizing the economic stability of the industry. This is done through legitimating tourism development as locally controlled and in the 'community's' interest" 28 . As we can see, Blackstock's criticism revolves around economical aspects. Others researchers prefer to highlight how CBT has developed along three different dimensions: involvement, power and control, and effects ${ }^{29}$. The first dimension, i.e. involvement and participation, implies an integration of the community in the issues affecting it. There are different kinds of participation, which occur in spaces created for this purpose, and are defined as invited spaces. The second dimension is that of power and control, evident from the relations between community and external stakeholders, and the way power is split between these two parties. The third dimension is that pertaining to the outcomes of Community Based Tourism, both inside and outside of the community. These authors suggest that an analysis of CBT should follow all three directions ${ }^{30}$.

\section{On the concept of community}

Like the concept of sustainability, also that of community, although widely used, is far from being univocally defined ${ }^{31}$. In classic sociology, the word evokes a type of social relation characterized by strong bonds and ties between its members and involves the individuals in the entirety of their reciprocal relationships. In contemporary sociology this word is usually synonymous with local community, i.e. a small community with a traditional culture. When analyzing the concepts of community and, more specifically, local community, Pollini describes the two main models:

1. The first is defined by the author as one of "linear development". This model postulates the replacement of primary interpersonal relationships with secondary ones, as a consequence of the increased number of inhabitants and population density ${ }^{32}$.

28 Ibidem: 44-45.

${ }^{29}$ Melphon Mayaka, W. Glen Croy and Julie Wolfram Cox, "A dimensional approach to community-based tourism: Recognising and differentiating form and context", Annals of Tourism Research 74 (2019): 177-190. https://doi.org/10.1016/j.annals.2018.12.002

${ }^{30}$ Ibidem: 179

${ }^{31}$ Fabio Berti, Per una sociologia della comunità (Milano: FrancoAngeli, 2005).

32 Academics employing this model are Tönnies, Weber, Durkheim and Parsons. Gabriele Pollini, "Turismo, comunità locale ed appartenenza socio-territoriale", in Turismo, fluidità relazionale e appartenenza territoriale, ed. by Renzo Gubert and Gabriele Pollini (Milano: FrancoAngeli, 2002), 15-90. 
2. The second model considers the community as an essential aspect of our present: local communities are a complex network of kinship, friendship, formal and informal trade and business relationships which are deeply rooted in everyday family life and the need to socialize ${ }^{33}$.

In today's society, small-community stakeholders are part of a network of economical, political, social and cultural relations that goes well beyond the local level. The possibility of interacting with countless contexts render these boundaries very fluid, to such an extent that one wonders whether they still exist or are progressively dissolving. On the other hand, the network of relations and the presence of "foreign" contexts can help reinforce the identity of a location and hence the feeling of being part of a community. Community thus becomes an antidote to uncertainty and the feeling of vulnerability deriving from the rapid changes of present-day life, wrapping a sense of belonging to a place considered to be a refuge from chaos $^{34}$.

The concept of community is a source of problems, but perhaps it is its "slipperiness" that makes it so popular ${ }^{35}$. In this respect, Amit and Rapport compare its nature to that of symbols, because "they evoke a thick assortment of meanings, presumptions and images. This kind of thickness doesn't make for precise definitions but it does ensure that the invocation of 'community' is likely to have far more emotional resonance than a more utilitarian term" 36 . Its evocative character makes it prone to cynical exploitation by the tourism industry, for instance, which plays a key role in the image-creating process of a certain place ${ }^{37}$. This has its consequences: imaginaries of tourist destinations include how the residents are presented (or ill-presented) $)^{38}$.

The principles inspiring community-based tourism are rather elementary and in many ways commendable: the approach is based on the fact that stakeholders involved in the process of tourism development not only have

33 This model is based on the approach employed by the first academics of the Chicago school of thought (Ibidem).

34 Doreen Massey, “A place called home”, New formations 17 (1992): 3-15. Ibidem: 13.

35 Vered Amit and Nigel Rapport. The Trouble with Community: Anthropological Reflections on Movement, Identity and Collectivity (London: Pluto, 2002).

36 Ibidem: 13-14.

37 Graham Dann, "People of tourist brochures". In The Tourist Image: Myths and Myth Making in Tourism edited by Tom Selwyn (New York: John Wiley and Sons, 1996), 61-81.

38 Noel B Salazar, "Community-based cultural tourism: Issues, threats and opportunities", Journal of Sustainable Tourism 20, no. 1 (2012): 9-22. https://doi.org/10.108 0/09669582.2011.596279: 9 
the right to be part of tourism-related trade and business, but also play an active role in all planning and policy-making processes ${ }^{39}$.

The socio-cultural impact of tourism on the local community entails a process of differentiation within the community, with a consequent segmentation of attitudes and opinions of the residents towards tourism. Highlighting the multi-faceted character of the community means admitting that there is no fixed, unchangeable relation between the elements which form a community.

Tourism is doubtlessly an active force. It would be a mistake however to believe that local communities live in a state of perfect balance. There can be a wide spectrum of views and opinions within a community, and given its dynamic, if not volatile nature, it can rapidly change the way it perceives tourists. Communities are by no means homogeneous in composition $^{40}$.

\section{Tourist imaginaries}

\section{On imaginary}

Imaginary can be viewed as the "ceaseless and essentially undetermined (social, historical and mental) creation of figures, forms and images [...]. What we call 'reality' and 'rationality' are therefore the result of our imaginary" "41. In this respect, it is without doubt a creative force. Imaginary is a mainstay of the tourism industry: a destination is not always selected on the

39 Mina Dragouni, Kalliopi Fouseki and Nikolaos Georgantzis, "Community participation in heritage tourism planning: is it too much to ask?", Journal of Sustainable Tourism 26, no. 5 (2018): 759-781. Doi: 10.1080/09669582.2017.1404606: 759.

See also, Douglas Pearce, "Alternative tourism: concepts, classifications and questions". In Tourism Alternatives: Potentials and Problems in the Development of Tourism, ed. by Valene L. Smith, and William R. Eadington (New York: John Wiley and Sons, 1992), 18-30. Eric Laws, Tourist Destination Management: Issues, Analysis and Policies (New York: Routledge, 1995). For an overview on the intersections between sustainable tourism and community-based tourism see Andrea Giampiccoli, Oliver Mtapuri, and Anna Dłużewska, "Investigating the intersection between sustainable tourism and community-based tourism", Tourism Review 68, no. 4 (2020): 415 - 433 https://doi.org/10.37741/t.68.4.4

Community-based tourism is also included in the document: United Nations World Tourism Organization [UNWTO] and United Nations Development Programme [UNDP], Tourism and the Sustainable Development Goals - Journey to 2030 (2017). https://www.e-unwto.org/doi/epdf/10.18111/9789284419340

40 Richard Sharpley, Tourism, tourists and society (Huntingdon: Elm, 2003), 10-15.

${ }^{41}$ Cornelius Castoriadis, L'istituzione immaginaria della società (Torino: Bollati Boringhieri, 1995), XXXVII-XXXVIII. 
grounds of its assets and features, but more usually because of its meaning for the collective imaginary. No place is a tourist destination in se, but becomes one after a transformation process aimed at making it meaningful for a considerable number of persons ${ }^{42}$. The creation of a place image or brand exploits mass communication media and an industry designed to make the tourist part of a fantastical dimension induced by the dream of going to a given destination. Likewise, tourism consumption is defined by a continuous process of selection and reorganization of meanings, all strongly interdependent: "Tourist imaginaries can be defined as spatial imaginaries that refer to the potential of a place as a tourist destination [...] They allow individuals and groups to imagine a place as a conceivable tourist destination; they create the desire, they render the place attractive, they help render travel plans concrete (by influencing both the selection of the place visited and the practices associated with undertaking the trip) [...] They intervene not only when choosing the destination, but also once there, directing, controlling or avoiding certain practices" ${ }^{\prime 3}$. Salazar is even more explicit when stating that tourism implies "the human capacity to imagine or to enter into the imaginings of others" 44 .

Given these premises, we can consider imaginary as a collective narrative construction that interacts with the images created by each individual to create meaning: imaginary thus produces meanings while contemporaneously being its result ${ }^{45}$.

Tourist imaginaries represent the whole set of (past-present-future) images regarding a destination, "refer to the potential of a place as a tourist destination", and not only intervene in the process of selection, the definition of the initial expectations concerning the place (including the activities offered within the territory, as highlighted by the recent development of specialinterest tourism ${ }^{46}$ ) and the expected experiences and practices, but also in the way tourists decide to interact and behave once there. In other words, these imaginaries help tourists approach a new (in cultural, social and spatial terms)

42 John Urry, Lo sguardo del turista. Il tempo libero e il viaggio nelle società contemporanee (Roma: Ed. Seam, 1995).

43 Maria Gravari-Barbas and Nelson Graburn, "Tourist imaginaries", published online on March 16, 2012. URL: http://journals.openedition.org/viatourism/1180; DOI : https://doi. org/10.4000/viatourism. 1180

${ }^{44}$ Noel B Salazar, "Community-based cultural tourism: Issues, threats and opportunities": 864.

45 Ibidem.

46 Norman Douglas, Ngaire Douglas and Ros Derrett (eds). Special Interest Tourism (Brisabe: Wiley, 2001).

Birgit Trauer, "Conceptualizing special interest tourism - frameworks for analysis", Tourism Mangement 27 (2006): 183-200. http://dx.doi.org/10.1016/j.tourman.2004.10.004 
environment and are the initial framework that will then contribute in determining the overall holiday satisfaction.

The construction of these imaginaries is an essential and complex aspect, given that they involve all the stakeholders: tourists, with their cultural background, intermediaries, professionals who are involved in actively creating the imaginary, and the hosting community: though largely ignored, the latter party should play a key role sustainable tourism development, because it concretely embodies the tourist-imaginary.

An involvement of local communities in tourism development is fundamental not only in response to the increasing attention towards issues of (environmental and social) sustainability, but for the whole process of image-building within a tourist destination.

\section{Participation as practice: creating the image of a place}

The project of which we herein describe some preliminary results is inspired from the concept of participation as practice; its objective is the involvement of residents in creating the tourism imaginary of the destination ${ }^{47}$. The goal is to analyze the social construction of the tourist imaginary, focusing both on the activity of the tourist stakeholders and the role played by the local community in the active creation and re-creation of collective representations associated to tangible and intangible cultural assets. In brief, we explore whether and to what extent the imaginary created by the stakeholders corresponds to that shared and negotiated at community level.

The research project also aims at promoting a change in the way the issue of the imaginary creation is discussed and implemented within the framework of tourism. The research assumes that the interaction among and between all the parties contributes to creating the tourist imaginary and giving it an accepted and widely-shared meaning.

The concept of participation used herein echoes the thoughts of Cotta and Pellizzoni ${ }^{48}$. According to the former author, "participation" refers to two different aspects: taking part in a specific process, and thus acting

47 The research presented here is part of Excover Project, part of the Interreg ItaCro Programm. Focus of the project is a community-led tourist development based on a sustainable valorisation of the natural and cultural resources of the territories involved: https://www.italy-croatia.eu/web/excover

48 Maurizio Cotta, "Il concetto di partecipazione politica: linee di inquadramento teorico", Rivista Italiana di Scienza Politica 9, no. 2 (1979): 103-227. Luigi Pellizzoni, “Cosa significa partecipare", Rassegna Italiana di Sociologia 3 (2005): 479-514. 
purposefully, and secondly, being part of an organization or community. This means that on one hand, participants are involved in specific actions and are asked to decide upon specific issues; on the other, it implies that they are part of a solidarity system, a community. In other words, individuals who belong to a community are involved in the actions: one cannot take part in without being part of, and vice versa ${ }^{49}$.

Participating does not simply mean cooperating; the will to act and agency (i.e. the possibility of acting) are of fundamental importance. With regard to the former aspect, it goes without saying that it is impossible to force participation; all relies on the willingness of individuals, who act out of interest, curiosity, or sense of responsibility. Agency, on the other hand refers to the possibility that an individual has to choose (hence, the opportunity to act upon certain events) $)^{50}$.

These clarifications help us distinguish between different degrees of participation: from mere cooperation to the possibility for an individual to decide for him/herself, influence collective decisions or even the structure of the decision-making process.

Another common misinterpretation occurs for the concepts of participation and consultation. While the former on implies an active role for the community, with its ultimate control over the decision process, the term consultation implies the "sharing of information but not necessarily power". Consultation does not influence the decision-making process ${ }^{51}$.

Participation to the planning and implementation of tourism policies has been unremittingly advocated: in general, whoever is affected by a decision has the right to take part in it. Participation represents a move from the global, top-down strategies dominating the first development projects to a more sensitive approach. In concrete terms, stakeholders and residents must have an active role in the decision-making process, expressing their opinions, making room for discussions about the issues at stake and facilitating consensus building, because only the involvement of all parties in the decision-making and product promotion processes can prevent the onset of tensions within the community. Hence participation becomes "an empowering process which enables local people to do their own analysis, to take command, to gain in confidence and to make their own decisions" 52 .

49 Maurizio Cotta, "Il concetto di partecipazione politica: linee di inquadramento teorico": 203-204

${ }^{50}$ Luigi Pellizzoni. "Cosa significa partecipare": 7

51 Tristan Claridge, Designing Social Capital Sensitive Participation Methodologies. 2004: 20. In https://www.socialcapitalresearch.com/wp-content/uploads/2013/01/SocialCapital-and-Participation-Theories.pdf?x15737 Accessed on October 15 $5^{\text {th }}, 2020$.

52 Ibidem: 23. 
Participation is not a linear process: issues such as who should be involved, to what extent and on whose terms are at stake: "While participation has the potential to challenge patterns of dominance, it may also be the means through which existing power relations are entrenched and reproduced. The arenas in which people perceive their interests and judge whether they can express them are not neutral" ${ }^{53}$. Participation is a dynamic process, from which different, if not clashing interests emerge.

As mentioned previously, people cannot be forced to participate. Participation is a voluntary act; in this project we adopted an invited participation approach, i.e. that orchestrated by an external agency of some kind $^{54}$. The mainstays of this type of strategy are: a) inclusion, given that various community groups are involved in the project; b) the sharing of aims and strategies; c) ensuring a continuous communication among partners and between partners and individuals or groups from the community.

Aim of the whole project is to involve the residents in creating the imaginary of their hometown, i.e. how the destination is presented to the potential tourist. We can now analyze the relationship between the image of a place, as it is presented to tourists, and the imaginary created, negotiated and shared at community level: do they match?

\section{The research project}

The research results presented in this paper are a part of a wider research project founded by the European program Interreg Italy-Croatia (Excover). Aim of the project is the tourist valorization of small towns and villages with very relevant historical, cultural and natural assets, but visited by a little number of tourists, lower than the potentiality of the local natural and cultural resources would allow 55 .

53 Sarah C. White, "Depoliticising Development: The Uses and Abuses of Participation", Development in Practice 6, no. 1 (1996): 6-15: 6. https://doi. org/10.1080/0961452961000157564

54 Andrea Cornwall, "Unpacking 'Participation': Models, Meanings, and Practices", Community Development Journal 43, no. 3, 2008: 269-283. doi:10.1093/cdj/bsn010

55 The territories involved in the Interreg Project Excover are: Lika-Senj County with the municipality of Gospić, Primorje-Gorski Kotar County and Karlovac County in Croatia; Unità Territoriale della Carnia (now Comunità di Montagna), the Municipality of Rive d'Arcano, Po Delta, the Municipality of Campobasso, the Interregional Park Authority of Sasso Simone e Simoncello, the Municipality of Predappio, the Local Action Group Montefeltro. In the project three Universities are involved as responsible for the activities: University of Udine, University of Bologna and University of Zadar. 
The core aspect of the project is therefore the involvement of the local communities, moving from the idea that only the participation of the residents will support a sustainable tourism development. This has been considered an essential part of the project itself, which is promoting a community-led participation process based on a sustainable valorization of the natural and cultural resources and on the development of the opportunities offered by the sharing economy. From the first phases of the project, the involvement of the locals has been supported. One of the activities included in the project was the development of 'Participatory Planning Processes' for identification of the cultural heritage to be integrated into the valorisation process of the destinations. Actually, this involvement has taken different strategies and forms in the various territories involved in the project: focus groups, seminars, workshops, one-to-one interviews, etc.; however, all the initiatives were led by the same connotation, that is a bottom up approach based on the participation of locals.

Participation is a voluntary act; the project is based upon what has been called invited participation, that is, participation of community members in a project which is initiated by an agency or organization. In this particular case, a group of actors has promoted the engagement with the larger community in order to develop a project of community-based tourism development which involves local population in the creation of the imaginary of a place (which will become, in a second stage of the project, a tourist product) ${ }^{56}$. The pillars on which this strategy relies are: a) inclusion, as various groups from the community are involved in the project; b) sharing, putting in common aims and strategies; c) constant communication among the partners and between partners and individuals and groups within the community.

Within this more general framework, in the following pages the first results of the field work conducted in one of the territories involved in the project will be presented. Aim of the field work was to explore what the locals conceive as heritage, what are the most relevant elements they would consider as local patrimony, which are the aspects that reveal the bond with the territory and the feelings of attachment and belonging to it ${ }^{57}$. By heritage we mean something handed down from the past, as a tradition,

56 The research presented here is part of Excover Project, part of the Interreg ItaCro Programm. Focus of the project is a community-led tourist development based on a sustainable valorisation of the natural and cultural resources of the territories involved: https://www.italy-croatia.eu/web/excover. Donatella Cozzi and Monica Pascoli are the responsible for the field work; Uti Carnia (now Comunità di Montagna) is the territorial partner that administratively supported the process.

57 Irwin Altman and Setha M. Low (eds), Place Attachment (New York-London: Plenum Press, 1992). 
which becomes the hallmark and identifying factor of a people, hence "a 'discursive construction' with material consequences". Heritage has been defined as the present-day look at the past, a very specific past, or the future. In both cases the viewpoint is the present: the perspective is therefore affected by the viewer's current concerns, and vision is limited, selective. This definition has significant consequences, including the fact that heritage responds to different, even clashing purposes and bears a variety of meanings: it is therefore intrinsically discordant or "dissonant" 58 .

The field work was exploratory, and was aimed at understanding whether the destination image created for promotional purposes coincided with that held true by the residents; in particular, the research was driven by the following research questions:

1. What do the residents consider their heritage? What are the most significant features of the area in the eyes of its residents?

2. Are the key attractions promoted by the tourism industry perceived as such by the residents? Or do they believe that others are the distinctive features of their territory?

\section{The context of the research}

"Situated at the centre of Val d'Incarojo and surrounded by wonderful woodland, Paularo is primarily known for its natural and alpine aspects. In fact, the area lends itself to excursions and walks that are able to satisfy even the most demanding of visitors. Even the centre of the town is worthy of a walk, to see the Palazzo Calice Screm, an architectural ensemble with characteristic loggias which are considered the prototype of the Carnian house, and the eighteenth century Palazzo Linussio Fabiani, residence of the family of Jacopo Linussio, creator of one of the biggest eighteenth century textile manufacturers [sic] in Europe. In the shops you can buy traditional Carnian artisanal items: rustic furniture, plates, bowls, boxes, wooden chopping boards, baskets and panniers, but also traditional clothes and scarpèts. Worthy of a visit is the Mozartina, a precious collection of old and modern musical instruments" 59 .

${ }^{58}$ Brian Graham, Greg J. Ashworth and John E. Tunbridge, A geography of heritage. Power, culture \& economy (London: Arnold, 2000: 2-3)

59 https://www.turismofvg.it/locality/paularo. Accessed January $10^{\text {th }}, 2021$.

See also http://www.comune.paularo.ud.it/index.php?id=21833\&L=606. Accessed January 10 th, 2021. 
This is the description of Paularo (2.477 inhabitants) and the Incarojo Valley published online on the homepage of PromoTurismoFVG, the official tourism-promoting agency in Friuli Venezia Giulia, north-eastern Italy. The words portray the main attractions of this rather secluded destination, located among the Carnia mountains, near the border with Austria. Carnia has always been a crossway of different people, in particular during the Middle Ages. In 1077 King Henry IV of Germany established the Patriarchate of Aquileia as an Imperial State, and Carnia became part of it. In 1420 it was conquered by the Republic of Venice, and remained under its power until 1797, when it fell under the AustroHungarian Empire. It was in 1866 that it became part of the Italian territory. From the point of view of tourism, the main attractions promoted both at local and regional levels are linked to the natural environment (trekking and sports). Cultural assets however are not neglected: these include the eighteenth-century church of Sts. Vito, Modesto and Crescenza, with its frescoes, the Church of Santa Maria Maggiore in Dierico, famous for its carved wooden altar, palazzo CaliceScrem (1591), palazzo Mocenigo-Linussio-Fabiani, dating back to the eighteenth century, palazzo Calice di Villafuori (1 $7^{\text {th }}$ century), Casa Scala ( $18^{\text {th }}$ century), with the "Mozartina", a private collection of pianos, pipe organs, and other ancient musical instruments. Tourism in this area is mostly short-termed (1-2 nights or weekend stays), and guests are usually families or adults (usually trekkers). Tourism is seasonal, with the greatest flows recorded in summertime, especially during specific events organized in the area (cultural and food festivals, mountain excursions, sports activities, and so forth). There are also religious celebrations that attract many visitors and in late August, a festival known as Mistîrs, which involves the whole community. The theme is ancient crafts and trades, and this event also serves to promote the eco-museum of this territory.

\section{Methodology}

This explorative investigation was carried out using a non-standard approach in defining both the framework of the survey and its structure. The reason for this choice was to ensure a satisfactory degree of freedom and flexibility to both interviewer and respondents.

Thirty-two individuals have been interviewed. The interview was unstructured and non-directive; it included questions about the territory, basically focusing on the respondents' opinion in relation to the most interesting characteristic of the place, what is considered most valuable 
and what, on the contrary, represents a problem. The field work took place from July to November $2020^{60}$. The meetings were organized mostly at the respondents' house, but took place also in public spaces.

The respondents, all residing in the town of Paularo, were selected through the snowball technique, to ensure an adequate variability in terms of gender, age and profession. It was decided not to involve persons active in the tourist sector, in an attempt to better understand the opinion of the residents, mostly native to the town, who were not directly involved in the debate on tourism development.

The facilitator, Agata Gridel, came from Carnia and, though not native of Paularo, was fluent in the local dialect. Her vast experience in community work (eco-museums and community maps), knowledge of the territory and lack of involvement in the sometimes-conflicting dynamics within the town ensured a successful outcome. Access to the field developed by accumulation: the facilitator involved some "friendly" contacts first, which in turn allowed to enter the broad community. Aim of the facilitator was to collect a heterogeneous group of informants (in terms of age, gender, working activities, etc.).

The surveys, either individual or in small groups ${ }^{61}$, took the shape of spontaneous, easy-going conversations; the relation-creating approach employed overcame any trace of wariness. The respondents were asked to talk about their territory, describing what were in their opinion its most interesting cultural and natural resources and why did they consider them so meaningful. They were also asked what places would they show to friends visiting them, and what experiences would they advise them to live. The purpose of the survey was to understand the image of the destination from the residents' viewpoint.

In a second stage, the contents of the interviews and focus groups have been analysed with the support of two different tools: a database form and the "Participatory Planning Process Report".

The database form collects all the information regarding the sites, attractions and experiences selected by the locals as the most relevant aspects of the territory. This will be incorporated in an interactive community map, which will present (and represent) the place as it is seen and interpreted by the residents: in other words, the visitor or the tourist

60 The research was supposed to start in February 2020, but the Covid-19 pandemic interrupted the fieldwork activities, that could start again only during the Summer Season. There were no limitations of movement during those months and the field work has been conducted without any problem.

${ }^{61}$ Despite the freedom of movement, for safety reasons we decided to organize the focus groups within families. 
will see the place through the eyes of the local, listen to the stories linked to those place told by its inhabitants, share their memories.

The "Participatory Planning Process Report" (PPP Report) organizes all the information in relation to the participatory process, that is the involvement of the locals. In particular, it presents the information in relation to the access to territory (information about the process of access/ entry in the territory), the interviewees and their characteristics, their contribution to the PPP, their attachment to the place and feeling of belonging to their community, their participation in the life of the community, etc.

In the following paragraph, the focus will be on the image of the place as it is conceived by the locals: the adoption a bottom up-approach in the image-making process of a tourist destination.

\section{$X$. First results}

The fieldwork reveals that the images promoted by the regional tourism authorities and those of the residents match, although in the latter case, imaginary is much richer and more articulated.

In other words, we are not in presence of a dissonant or contrasting heritage and the aspects that are considered more "valuable", "attractive", "interesting" by the tourist promoting authority are in line with those selected and narrated by the local population.

Nevertheless, there are some substantial differences, which are related to: a) how the cultural and natural heritage (that represent the tourist attractions) should be experienced, according to the locals; b) the hidden heritage; c) the community life.

In relation to the first element, we should note that the environmental and cultural resources mentioned by the locals frequently coincide with those promoted by tourism offices, but the contexts of experience differ substantially. In other words, while the natural and historical heritage is fully and widely recognised both by the tourism sector and by the locals, it is the meaning of that heritage that changes. For instance, trekking itineraries and walks along the narrow streets of the villages would follow different routes, including stairways leading to hidden vantage points, or the little-known springs of iron and sulphur waters; according to one interviewee, walks should take place at night, to experience the silence for which this valley is so famous. Churches and palazzos are usually described in a heartfelt, subjective manner, dotting the narrative with stories passed down from their ancestors or more recent anecdotes of the community. 
The better-known attractions promoted by tourism however are only a small part of the destination's heritage. The respondents spoke about places that were extremely meaningful for them despite not even being mentioned in most of the promotional material issued by tourist offices: the trenches and galleries dug during First World War, for instance, the fortress of the "Vallo Littorio", dating back to the Fascist period, or remote, uninhabited hamlets. These hidden places, completely ignored by tourists, are distinctive elements that, according to the locals, make Paularo and the Incarojo Valley a unique place.

The most interesting elements that emerged during the interviews however concern community life, and its identity-bearing heritage: the legends and tales of the older folk, or the stories revolving around traditional crafts and trades, such as basket-weaving, an essential activity for carrying wood or for other daily tasks, and the old community dairy where the residents brought or bought milk. One of the hallmarks of the territory is hand embroidery, an art that in the eighteenth-century was at the heart of the local textile industry. The tradition has now been revived by a local association, the aim of which is to promote the handiwork beyond the boundaries of the valley.

\section{Conclusion}

Approaches to the concept of sustainability are manifold, all reflecting "different ethical positions and entailing varying policy objectives and management strategies" 62 . The authors note seven dimensions of sustainability: environmental, cultural, political, economic, social, managerial and governmental, all closely interlaced ${ }^{63}$. Our analysis of the concept of social sustainability originates from studies on the social impacts of tourism, which from the Nineteen Seventies onwards have become quite evident in many popular destinations of mass tourism. Said impacts can be defined as a network of relations arising from the interaction between how the territory is used by the visitors and the responses of the residences aimed at exploiting the benefits and minimizing the drawbacks of tourism development. Cohen lists many, including those more pertinent to our research: the involvement of the community in a wider network of relations, the development of interpersonal relationships, the redistribution

62 Bill Bramwell and Angela Sharman, "Approaches to Sustainable Tourism Planning and Community Participation". In Tourism and Sustainable Tourism Development, ed. by Derek Hall and Greg Richards (London: Routledge, 2000), 17-35. Ibidem: 18.

63 Ibidem: 32. 
of power, changes in local customs and arts ${ }^{64}$. Attention towards the community translates into the need to establish a negotiation relationship between the various stakeholders, given that the tourism industry can become a source of benefits if the planning process focuses on the community. The approach employed is therefore community-based, so as to maximize the participation of the residents from the very first stages of planning and allow the social construction of tourism development. When analyzing the idea of social sustainability, it became obvious that it should be related to other two concepts: participation, intended both as taking part and being part, and community.

The meaning of the word "community" is polysemous and often disputed. The interpretation we gave it is that defined by Clemente, who claims that a community is "neither a condition nor a set of practices, and not even a collective imaginary, but an ever-changing plural subjectivity involved in the project-action-process-solidarity cycle" 65 . Within the framework of our investigation on sustainable tourism development, the residents were asked to identify their heritage, hence the material and immaterial resources ${ }^{66}$ they believed were most meaningful and important. Through this process, "the immaterial cultural heritage handed down from generation to generation is continuously recreated by communities and groups of individuals [...], giving them a sense of identity and consistency" ${ }^{\prime 67}$. In our case, the concept of social sustainability translated as the participation of the residents in the image-creation process relative to their territory and community. The concept of community, as we understand it, is not a crystallized entity of which one can grasp the essence, but rather, "a field of mobile forces" 68 sharing a territory and a set of cultural elements with which it identifies itself. Our investigation revealed that there are no conflicting elements between the heritage selected through a top-down process and that identified by the residents.

${ }^{64}$ Erik Cohen, "The Sociology of Tourism: Approaches, Issues, and Findings", Annual Review of Sociology 10 (1984): 373-392. Ibidem: 382.

65 Pietro Clemente, "Communitas", Antropologia Museale, 37-39 (2017): 11-15. Ibidem: 12.

${ }^{66}$ In 2003 UNESCO promoted the Convention for the Safeguarding of the Intangible Cultural Heritage, identified in the "traditions or living expressions inherited from our ancestors and passed on to our descendants, such as oral traditions, performing arts, social practices, rituals, festive events, knowledge and practices concerning nature and the universe or the knowledge and skills to produce traditional crafts". Even more explicitly, during the Faro Convention (Council of Europe Framework Convention on the Value of Cultural Heritage for Society), it was agreed that both cultural heritage and rights of the residents to access and participate in said heritage should be protected.
${ }^{67}$ Ibidem.
68 Ibidem: 13. 
The symbolic representation of tourist attractions selected, presented and sold by tourist boards to potential visitors and trekkers is not dissonant 69 from that of the local community. There is however a great difference in how the material heritage is "lived", the residents having a much richer and more articulated experience, and the importance given to immaterial assets: tales and legends in particular are extremely meaningful for the locals, but are almost ignored by tourism stakeholders.

\section{References}

Altman, Irwin, and Setha M. Low (eds). Place Attachment. New York-London: Plenum Press, 1992.

Amit, Vered and Nigel Rapport. The Trouble with Community: Anthropological Reflections on Movement, Identity and Collectivity. London: Pluto, 2002.

Ap, John, and John L. Crompton. "Developing and testing a tourism impact scale". Journal of Travel Research 37(2) (1998): 120-130.

Ashworth, Gregory J. "Heritage, identity and places: for tourists and host communities". In Tourism in destination communities, edited by Shalini Singh, Dallen Timothy and Ross K. Dowling, 79-97. Wallingford: CABI, 2003.

Berti, Fabio. Per una sociologia della comunità. Milano: FrancoAngeli, 2005.

Blackstock, Kirsty. "A critical look at community based tourism". Community Development Journal 40, no. 1 (2005): 39-49.

Boissevain, Jeremy. Coping with Tourists. European Reaction to Mass Tourism. Oxford-New York: Berghahn Books, 1996.

Boyd, Stephen, and Shalini Singh. "Destination communities: structures, resources and types". In Tourism in destination communities, edited by Shalini Singh, Dallen Timothy and Ross K. Dowling, 19-33. Wallingford: CABI, 2003.

Butler, Richard. "The concept of the tourist area cycle of evolution: implications for the management of resources". Canadian Geographer 24 (1980): 5-12.

Castoriadis, Cornelius. L'istituzione immaginaria della società. Torino: Bollati Boringhieri, 1995.

Choi, Hwan-Suk Chris, and Ercan Sirakaya. (2005). "Measuring residents' attitude toward sustainable tourism: development of sustainable tourism attitude scale". Journal of Travel Research 43, no. 4: 380-394

Claridge, Tristan. Designing Social Capital Sensitive Participation Methodologies. 2004. In https://www.socialcapitalresearch.com/wp-content/uploads/2013/01/ Social-Capital-and-Participation-Theories.pdf?x15737 . Accessed on October $15^{\text {th }}, 2020$.

Clemente, Pietro. “Communitas”. Antropologia Museale, $37-39$ (2017): 11-15.

${ }^{69}$ Brian Graham, Greg J. Ashworth and John E. Tunbridge, A geography of heritage. Power, culture \& economy (London: Arnold, 2000). 
Cohen, Erik. "A phenomenology of tourist experiences". Sociology 13, no. 2 (1979): 179-201.

Cohen, Erik. "The Sociology of Tourism: Approaches, Issues, and Findings". Annual Review of Sociology 10 (1984): 373-392.

Cooper, Chris and Stephen Wanhill, eds. Tourism development. Environmental and community issues. Chichester: Wiley, 1997.

Cornwall, Andrea. "Unpacking 'Participation': Models, Meanings, and Practices". Community Development Journal 43, no. 3, 2008: 269-283.

Cotta, Maurizio. "Il concetto di partecipazione politica: linee di inquadramento teorico". Rivista Italiana di Scienza Politica 9, no. 2 (1979): 103-227.

Dann, Graham. "People of tourist brochures". In The Tourist Image: Myths and Myth Making in Tourism edited by Tom Selwyn, 61-81. New York: John Wiley and Sons, 1996.

De Kadt, Emanuel. Tourism. Passport to development? . Oxford: Oxford University Press, 1979.

Deery, Margaret, Leo Jago, and Liz Fredline. "Rethinking Social Impacts of Tourism Research: A New Research Agenda". Tourism Management 33, no. 1 (2012): 64-73. https://doi.org/10.1016/j.tourman.2011.01.026

Doğan, Hasan Zafer. "Forms of adjustment: sociocultural impacts of tourism". Annals of Tourism Research 16, no. 2 (1989): 216-236.

Douglas, Norman, Ngaire Douglas, and Ros Derrett (eds). Special Interest Tourism. Brisabe: Wiley, 2001.

Dragouni, Mina, Kalliopi Fouseki and Nikolaos Georgantzis. "Community participation in heritage tourism planning: is it too much to ask?". Journal of Sustainable Tourism 26, no. 5 (2018): 759-781. Doi: 10.1080/09669582.2017.1404606

Giampiccoli, Andrea, Oliver Mtapuri, and Anna Dłużewska. "Investigating the intersection between sustainable tourism and community-based tourism". Tourism Review 68, no. 4 (2020): 415 - 433 https://doi.org/10.37741/t.68.4.4

Graham, Brian, Greg J. Ashworth and John E. Tunbridge. A geography of heritage. Power, culture \& economy. London: Arnold, 2000.

Maria Gravari-Barbas and Nelson Graburn, "Tourist imaginaries", published online on March 16, 2012. URL: http://journals.openedition.org/viatourism/1180; DOI : https://doi.org/10.4000/viatourism.1180

Laws, Eric. Tourist Destination Management: Issues, Analysis and Policies. New York: Routledge, 1995.

Leed, Eric. La mente del viaggiatore. Bologna: il Mulino, 1992.

Liu, Juanita C., Pauline J.Sheldon and Turgut Var. "Resident perception of the environmental impacts of tourism". Annals of Tourism Research 14, no. 1 (1987): 17-37.

Macbeth, Jim. "Towards an Ethics Platform for Tourism". Annals of Tourism Research 32, no. 4 (2005): 962-984.

Massey, Doreen. “A place called home”. New formations 17 (1992): 3-15.

Massey, Doreen. Space, place, gender. Cambridge: Polity Press, 1994.

Mathieson Alister and Geoffrey Wall. Tourism: economic, physical and social impacts. London: Longman, 1982. 
Mayaka, Melphon, W. Glen Croy, and Julie Wolfram Cox. "A dimensional approach to community-based tourism: Recognising and differentiating form and context". Annals of Tourism Research 74 (2019): 177-190. https://doi. org/10.1016/j.annals.2018.12.002

Mowforth, Martin, and Ian Munt. Tourism and sustainability. New tourism in the Third World. London-New York: Routledge, 1998.

Murphy, Peter E. Tourism. A community approach. New York: Methuen, 1985.

Page, Stephen and Ross Dowling. Ecotourism. Harlow: Prentice Hall, 2002.

Pearce, Douglas. "Alternative tourism: concepts, classifications and questions". In Tourism Alternatives: Potentials and Problems in the Development of Tourism, edited by Valene L. Smith, and William R. Eadington, 18-30. New York: John Wiley and Sons, 1992.

Pellizzoni, Luigi. "Cosa significa partecipare”. Rassegna Italiana di Sociologia 3 (2005): 479-514.

Pollice, Fabio. Territori del turismo. Una lettura geografica delle politiche del turismo. Milano: FrancoAngeli, 2002.

Pollini, Gabriele. "Turismo, comunità locale ed appartenenza socio-territoriale”. In Turismo, fluidità relazionale e appartenenza territoriale, edited by Renzo Gubert, and Gabriele Pollini, 15-90. Milano: FrancoAngeli, 2002.

Pollini, Gabriele. "Elements of a Theory of Place Attachment and Socio-Territorial Belonging”. International Review of Sociology 15, no. 3 (2005): 497-515.

Robinson, Mike and Priscilla Boniface, eds. Tourism and Cultural Conflicts. Wallingford: CABI, 1999.

Ryan, Chris. Recreational tourism. Demand and impacts. Clevendon: Channel View, 2003.

Saarinen, Jarkko. "Traditions of sustainability in tourism studies". Annals of Tourism Research 33, no. 4 (2006): 1121-1140. https://doi.org/10.1016/j.annals.2006.06.007

Salazar, Noel B. "Community-based cultural tourism: Issues, threats and opportunities”. Journal of Sustainable Tourism 20, no. 1 (2012): 9-22. https://doi.org/10. 1080/09669582.2011.596279

Savelli, Asterio. Sociologia del turismo. Milano: FrancoAngeli, 2012.

Sharpley, Richard. Tourism, tourists and society. Huntingdon: Elm, 2003.

Simonicca, Alessandro. "Teoria e prassi dell'heritage tourism". In Turismo e sostenibilità. Risorse locali e promozione turistica come valore, edited by Lucilla Rami Ceci, 133-155. Roma: Armando Editore, 2005.

Singh, Shalini, Dallen, Timothy, and Ross K. Dowling. Tourism in destination communities. Wallingford: CABI, 2003.

Smith, Valene (ed). Hosts and guests. The anthropology of tourism. Philadelphia: University of Pennsylvania Press, 1977.

Tosun, Cevat. "Host perceptions of impacts: a comparative tourism study". Annals of Tourism Research 29, no. 1 (2001): 231-253. https://doi.org/10.1016/S01607383(01)00039-1

Trauer, Birgit. "Conceptualizing special interest tourism - frameworks for analysis”. Tourism Mangement 27 (2006): 183-200. http://dx.doi.org/10.1016/j.tourman.2004.10.004 
Turner, Louis and John Ash. The golden hordes. International tourism and the pleasure periphery. London: Constable, 1975.

Tusini, Stefania. La ricerca come relazione. Milano: FrancoAngeli, 2006.

United Nations World Tourism Organization [UNWTO] and United Nations Development Programme [UNDP], Tourism and the Sustainable Development Goals - Journey to 2030 (2017). https://www.e-unwto.org/doi/ epdf/10.18111/9789284419340

Urry, John. Lo sguardo del turista. Il tempo libero e il viaggio nelle società contemporanee. Roma: Ed. Seam, 1995.

Wall, Geoffrey. "Rethinking impacts of tourism". In Progress in Tourism and Hospitality Research 2, no. 3-4 (1996): 207-215. https://doi.org/10.1002/ pth.6070020302

White, Sarah C. "Depoliticising Development: The Uses and Abuses of Participation". Development in Practice 6, no. 1 (1996): 6-15. https://doi. org/10.1080/0961452961000157564

Williams, Stephen. Tourism geography. London-New York: Routledge, 1998.

World Tourism Organization. "Manila Declaration on the Social Impacts of Tourism". Accessed October 15th 2020 . https://www.e-unwto.org/doi/ pdf/10.18111/unwtodeclarations.1997.07.02

\section{About the author}

Monica Pascoli, PhD, is Research Fellow in Sociology at the University of Udine and lecturer of Sociology and Methodology of Social Research at the Universities of Udine and Trieste, Italy. She is part of the Euroculture Master Programme teaching staff (Erasmus Mundus Programme of Excellence).She is currently working on an EU funded project on community-based tourism development, focusing on the community involvement in the creation of the tourism image of a destination. Her research interests comprise tourism and the memory of the First World War, socio cultural impacts of tourism development, risk behavior in adolescence. Her recent works are Il turismo della memoria in Friuli Venezia Giulia (with A. Pocecco, FrancoAngeli, forthcoming), Italy (in Tourism Governance. A Critical Discourse on a Global Industry, De Gruyter, forthcoming), Le indagini sulle generazioni fragili (in Nuovi sentieri sociologici, FrancoAngeli, 2018), Young Italians in Search of Opportunities: The Image of Europe as a Lifeline (in Visions and Revisions of Europe, Göttingen University Press, 2018). 


\section{Sobre la autora}

Monica Pascoli es Doctora e Investigadora en Sociología, así como Profesora de Sociología y Metodología de Investigación Social en las Universidades de Udine y Trieste (Italia). Participa como docente en el Programa de Excelencia Erasmus Mundus de Eurocultura. Actualmente, se encuentra trabajando en un proyecto financiado por la UE sobre el desarrollo del turismo basado en la comunidad, orientado a la promoción de la implicación comunitaria en la creación de una imagen turística de destino. Su interés investigador se centra en el turismo y la memoria de la Primera Guerra Mundial, los impactos socio culturales del desarrollo del turismo y el comportamiento de riesgo en la adolescencia. Algunos de sus trabajos recientes son Il turismo della memoria in Friuli Venezia Giulia (con A. Pocecco, FrancoAngeli, pendiente de publicarse), Italy (en Tourism Governance. A Critical Discourse on a Global Industry, De Gruyter, forthcoming), Le indagini sulle generazioni fragili (in Nuovi sentieri sociologici, FrancoAngeli, 2018), Young Italians in Search of Opportunities: The Image of Europe as a Lifeline (in Visions and Revisions of Europe, Göttingen University Press, 2018). 


\section{Derechos de autor}

Los derechos de autor (para la distribución, comunicación pública, reproducción e inclusión en bases de datos de indexación y repositorios institucionales) de esta publicación (Cuadernos Europeos de Deusto, CED) pertenecen a la editorial Universidad de Deusto. El acceso al contenido digital de cualquier número de Cuadernos Europeos de Deusto es gratuito inmediatamente después de su publicación. Los trabajos podrán leerse, descargarse, copiar y difundir en cualquier medio sin fines comerciales y según lo previsto por la ley; sin la previa autorización de la Editorial (Universidad de Deusto) o el autor. Así mismo, los trabajos editados en CED pueden ser publicados con posterioridad en otros medios o revistas, siempre que el autor indique con claridad y en la primera nota a pie de página que el trabajo se publicó por primera vez en CED, con indicación del número, año, páginas y DOI (si procede). Cualquier otro uso de su contenido en cualquier medio o formato, ahora conocido o desarrollado en el futuro, requiere el permiso previo por escrito del titular de los derechos de autor.

\section{Copyright}

Copyright (for distribution, public communication, reproduction and inclusion in indexation databases and institutional repositories) of this publication (Cuadernos Europeos de Deusto, CED) belongs to the publisher University of Deusto. Access to the digital content of any Issue of Cuadernos Europeos de Deusto is free upon its publication. The content can be read, downloaded, copied, and distributed freely in any medium only for non-commercial purposes and in accordance with any applicable copyright legislation, without prior permission from the copyright holder (University of Deusto) or the author. Thus, the content of CED can be subsequently published in other media or journals, as long as the author clearly indicates in the first footnote that the work was published in CED for the first time, indicating the Issue number, year, pages, and DOI (if applicable). Any other use of its content in any medium or format, now known or developed in the future, requires prior written permission of the copyright holder. 